\title{
One Life Only: Biological Resistance, Political Resistance
}

Catherine Malabou

Translated by Carolyn Shread

That a resistance to what is known today as biopower-the control, regulation, exploitation and instrumentalization of the living being — might emerge from possibilities written into the structure of the living being itself, not from the philosophical concepts that tower over it; that there might be a biological resistance to the biopolitical; that the biomight be viewed as a complex and contradictory authority, opposed to itself and referring to both the ideological vehicle of modern sovereignty and to that which holds it in check: this, apparently, has never been thought.

\section{Philosophy's Antibiological Bias}

What am I saying? It's a fact that in our time we have witnessed the definitive erasure of the limit between the political subject and the living subject that for centuries was believed to be secure. Michel Foucault illuminated magnificently the erasure of this limit, an erasure that marked the birth of the biopolitical and acts as the characteristic trait of modern sovereignty: "For millennia, man remained what he was for Aristotle: a living animal with 
the additional capacity for a political existence; modern man is an animal whose politics places his existence as a living being in question.”"

These celebrated remarks define biopower as the means by which life is introduced "into political techniques." On the threshold of modernity, power was exercised over "life processes and undertook to control and modify them” (HSI, p. 142). In Homo Sacer, Giorgio Agamben returns to the analysis of this undifferentiated zone between biological life and political life that defined the space of community from that point on. ${ }^{2}$ The living being entered politics once and for all.

And yet we have to admit that this "entry" is unilateral, nondialectical, unreciprocated. The "double and crisscrossing politicization of life and the biologization of politics” take place without tension because the biological is deprived of the right to respond

This essay was originally published in French as Catherine Malabou, "Une Seule Vie: résistance biologique, résistance politique,” Esprit (Jan. 2015): 30-40.

1. Michel Foucault, The History of Sexuality: An Introduction, vol. 1 of The History of Sexuality, trans. Robert Hurley (New York, 1978), p. 143; hereafter abbreviated HSI.

${ }^{2}$ See Giorgio Agamben, Homo Sacer: Sovereign Power and Bare Life, trans. Daniel HellerRoazen (Stanford, 1998). 
and appears to simply flow into the mold of power. ${ }^{3}$ It's all as if, since its birth in the eighteenth century, biology were preparing itself for its political investiture by offering renegade categories to power. Indeed, according to Foucault, all "biological concepts" have a “comprehensive, transferable character" ${ }^{4}$ by which they exceed their technical significance and take on a normative meaning. Yet the political becoming of biological concepts moves only in one direction: the control and regulation of both individuals and populations. Apparently, there cannot be any biopolitical resistance to the biopolitical.

Taking this point of view to the extreme, Agamben does not hesitate to say that Nazism did not even have to adapt genetic concepts to its ends; they sat, as it were, ready for use:

It is important to observe that Nazism, contrary to a common prejudice, did not limit itself to using and twisting scientific concepts for its own ends. The relationship between National Socialist ideology and the social and biological sciences of the

${ }^{3}$. Roberto Esposito, Terms of the Political: Community, Immunity, Biopolitics, trans.

Rhiannon Noel Welch (New York, 2013), p. 71.

4. Foucault, The Birth of the Clinic: An Archaeology of Medical Perception, trans. A. M. Sheridan Smith (New York, 1994), p. 35. 
time — in particular, genetics_-is more intimate and complex and, at the same time, more disturbing. ${ }^{5}$

In the same vein, Roberto Esposito does not hesitate to write that Nazism "is actually biology realized.”6

This way of thinking clearly leaves aside everything in biology that is not related to the training of bodies or the regulating of conduct and instead reveals the reserve of possibilities inscribed in the living being itself. It is a dimension confirmed by the revolutionary discoveries of molecular and cellular biology today. These discoveries, which are largely ignored by philosophers, are the very ones able to renew the political question. This can be demonstrated via two central categories. The first is the epigenetic. The second is cloning, with its two fields of operation: asexual reproduction and regeneration (or selfhealing).

I am well aware that I am dealing with explosive notions here, notions that more often than not function as the privileged tools of contemporary biopolitics and its industrial, biologist and eugenicist offshoots. Nonetheless, it is my contention that these categories allow us to reconsider the antibiological bias of philosophy.

${ }^{5}$. Agamben, Homo Sacer, pp. 145-46; hereafter abbreviated HS.

6. Esposito, Terms of the Political, p. 80. 
What bias? Contemporary philosophy bears the marks of a primacy of symbolic life over biological life that has not been criticized, nor deconstructed.

Symbolic life is that which exceeds biological life, conferring meaning on it. If refers to spiritual life, life as a "work of art," life as care for the self and the shaping of being, peeling our presence in the world away from its solely obscure, natural dimension.

Foucault's concept of body and Agamben's concept of bare life bear witness to this unquestioned splitting of the concept of life. Paradoxically, they expel the biological that is supposed to constitute their core-and it thereby becomes their unthinkable residue.

Let's go back to the phrase in The History of Sexuality: “modern man is an animal whose politics places his existence as a living being in question.” Foucault is swift to equate "existence as a living being” with the body: “The purpose of the present study is in fact to show how deployments of power are directly connected to the body” (HSI, p. 151).

The body acts as a hyphen connecting "anatomy, the biological, the functional” and is the lowest common denominator in the various determinants that supposedly describe the specificity of the "living being": the "fact of living," "to be a living species in a living world"- having conditions of existence, life probabilities; individual and collective health (HSI, pp. 151, 142).

Yet it is immediately clear that in fact the body is 1) all and part of a list in which the biological is defined diffusely: "bodies, functions, physiological processes, sensations, and 
pleasures” or as “organs, somatic localizations, functions, anatomo-physiological systems, sensations, and pleasures”; 2) that it both is and is not reducible to the biological. The biological is said to be "what is most material and most vital” in bodies (HSI, pp. 152, 15253, 152). How should we understand this? That in the body there is something more and less vital, more and less material? If so, then that means that the "less vital" and "less material" is that which is incorporeal in the body: the spiritual or the symbolic.

The same problem arises for the bare life that Agamben borrows from Walter Benjamin (bloss Leben) and that constitutes a central category in his analysis of the biopolitical. In many respects, bare life seems to merge with biological life. It relates to the "simple fact of living” and refers to "natural life” (for which there is neither good nor evil but only “the pleasant and the painful”)_-“biological life as such” (HS, p. 1, 3). It is often described as "pure” or "simple”: "simple fact of living," "simple natural life” (HS, pp. 182, 3). But it is also synonymous with the body: "simple living body," docile body ("power penetrates subjects’ very bodies”) (HS, p. 3, 5). But here we find the same confusion. As Agamben writes, "Bare life ... now dwells in the biological body of every living being” (HS, p. 140). Once again, therefore, there is space for something other than bare life in the biological body. And in what, then, does that which is not in the bare life of this body consist? More precisely, we come to see, bare life is that which lives in the biological body without being reducible to it—its symbol. 
It must be said, the biologists are of little help with this problem. Not one has deemed it necessary to respond to the philosophers or to efface the assimilation of biology to biologism. It seems inconceivable that they do not know Foucault, that they have never encountered the word biopolitical. Fixated on the two poles of ethics and evolutionism, they do not think through the way in which the science of the living being could—and from this point on should — unsettle the equation between biological determination and political normalization. The ethical shield with which biological discourse is surrounded today does not suffice to define the space of a theoretical disobedience to accusations of complicity among the science of the living being, capitalism, and the technological manipulation of life.

\section{The Gap between the Living Being and Itself}

In order to lay out the foundations of the discussion would require asking (is this sentence correct ?) contemporary biology “permission,” to use Georges Canguilhem’s phrase, to identify its "fundamental philosophical concepts.",

Epigenetics and cloning are some of these fundamental concepts, linked by a set of complex relations that position the living being as the center of interactions.

\footnotetext{
${ }^{7}$. Georges Canguilhem, Knowledge of Life, trans. Stefanos Geroulanos and Daniela Ginsburg, ed. Paola Marrati and Todd Meyers (New York, 2008), p. 59.
} 
In the first instance (epigenetics), interactions occur between two systems of transmission of hereditary information, as much at the level of individual development (ontogenetic development) as at the level of the perpetuation of the characteristics of the species (phylogenetic heredity). In the second instance (cloning), exchanges take place between two regimes of reproduction: procreation and the transfer of the nucleus. Each of these two cases reveals the living being as an open structure in which the plural regimes of transmission of memory and inheritance intersect.

"What is most material and most vital in bodies" must be thought as an interactive space, a formative and transformative dynamic of organic identity that operates within the economy of the living being itself, not outside of it. The gap that is opened between the living being and itself through the double interface between regimes of transmission and regimes of reproduction is a paradoxical memory gap in that it reveals the now fundamental shifting between the irreversibility and reversibility of difference.

\section{Epigenetics}

First and foremost, epigenetics allows us to question the definition of the living being as a set of functions; secondly, it makes it possible to question the definition of the living being as a program; thirdly, it blurs the dividing line between the fact of living and the elaboration of a mode of being. The word epigenetic comes from the noun epigenesis (from 
the Greek, epi, above, next to, and genesis; epigenesis thus literally means "above or next to genesis”), which appeared in the seventeenth century in reference to a biological theory that claimed that the embryo develops through gradual differentiation of parts, thereby opposing preformationism. By contrast, preformationism assumes that the living organism is wholly constituted in advance, as a miniature, in the seed.

Something remains of epigenesis in contemporary epigenetics, as this is a science that does indeed have a certain type of gradual and differentiated development as its object. The term was used for the first time by Conrad Waddington in 1941 to refer to the area of biology that deals with relations between genes and the phenotype, that is, the set of observable characteristics of an individual for which they are responsible. ${ }^{8}$ The study of hereditary and reversible changes in the function of genes that take place without altering this sequence is thus called epigenetics. Since the 1970s, epigenetics has covered the set of mechanisms that control genetic expression via transcription through RNA and modify the action of genes without modifying the DNA sequence. Known primarily for its role as a messenger that transfers the genetic information of DNA towards the manufacturing sites of proteins situated outside the cell nucleus, RNA is increasingly recognized as being a key actor in epigenetic history. But what is it that we call epigenetic history?

${ }^{8}$. See C. H. Waddington, “The Basic Ideas of Biology,” in Prolegomena, vol. 1 of Towards a Theoretical Biology, ed. Waddington (Edinburgh, 1968), pp. 1-32. . 
Firstly, epigenetic history concerns an essential dimension of ontogenetic

development. Thomas Morgan already articulated the need to have recourse to epigenetic phenomena in order to understand individual development when he asked: "If the characters of the individual are determined by the genes, then why are not all the cells of the body exactly alike?" ${ }^{9}$ Since each cell of a single organism has the same genetic heritage, we must presume the existence of differential gene expression. Epigenetic mechanisms are this expression, which is concerned essentially with cellular differentiation and the methylation of DNA via RNA, which either favors or weakens the transcription of code.

The notion of epigenetic history also refers to a type of heredity, that is, once again, a specific mode of transmission of information from one generation to the next, hence the importance of its phylogenetic dimension. In Evolution in Four Dimensions, Eva Jablonka and Marion Lamb, who go so far as to speak of the "epigenetic turn” of our era, emphasize the fact that genetic transmission is not the sole mode of hereditary transmission: "The idea that DNA alone is responsible for all the hereditary differences between individuals is now so firmly fixed in people's minds that it is difficult to rid them of it"; the idea that "information

\footnotetext{
${ }^{9}$. Thomas H. Morgan, “The Relation of Genetics to Physiology and Medicine,” Nobel prize lecture, 4 June 1934, www.nobelprize.org/nobel_prizes/medicine/laureates/1933/morganlecture.pdf, p. 323.
} 
transmitted through nongenetic inheritance systems is of real importance for understanding heredity and evolution" is not yet accepted. ${ }^{10}$

And yet, epigenetic heredity is indisputable today. Epigenetic modifications in fact have the particular quality of being heritable from one generation of cell to the next, ${ }^{11}$ which renders the idea of evolution more complex and reveals its multiple dimensions.

Lastly, the notion of epigenetic history relates to the way in which the modifications of the master of the genes depend not only on internal and structural factors, like those mentioned above, but also on environmental factors.

So the epigenetic also provides genetic material with a means of reacting to the evolution of environmental conditions. Although plants have neither a nervous system nor a brain, their cells do have the ability to memorize seasonal change. Reactions to environmental conditions are even greater among animals. Laboratory studies of consanguine mice have recently shown that a change in food regime can influence their offspring. The young have brown, yellow, or dappled fur depending on this change. When females in gestation receive a certain food, their offspring develop mainly brown fur. Most of the young

\footnotetext{
${ }^{10}$. Eva Jablonka and Marion Lamb, Evolution in Four Dimensions, Genetic, Epigenetic,
} Behavioral, and Symbolic Variation in the History of Life (Cambridge, Mass., 2005), p. 109.

${ }^{11}$. This occurs during mitosis_-or even over several generations of organisms during meiosis_- even if the cause has disappeared. 
born of control mice (which did not receive the additional food) had yellow or dappled fur.

There is therefore a transmissible memory of changes due to environment.

Thomas Jenuwein, director of the Department of Immunobiology at the Max Planck

Institute, suggests that:

The difference between genetics and epigenetics can probably be compared to the difference between writing and reading a book. Once a book is written, the text (the genes or DNA: stored information) will be the same in all the copies distributed to the interested audience. However, each individual reader of a given book may interpret the story differently, with varying emotions and projections as they continue to unfold the chapters. In a very similar manner, epigenetics would allow different interpretations of a fixed template (the book or genetic code) and result in different readings, dependent upon the variable conditions under which the template is interrogated. $^{12}$

The living being does not simply perform a program. If the structure of the living being is an intersection between a given and a construction, it becomes difficult to establish a strict border between natural necessity and self-invention.

\footnotetext{
12. Quoted in Brona McVittie, “Definition of Epigenetics,” Epigenetics, www.epigenesys.eu/en/articles/in-brief/196-definition-of-epigenetics
} 


\section{Cloning}

Let's turn now to cloning. In order to approach cloning as a new conceptual category proposed to thinking by contemporary biology, it is important to return to the problem referred to above regarding the interplay between the reversibility and irreversibility of difference. An interplay that "definitively shakes up our conceptions about the irreversible nature of processes of cellular differentiation.”13

The first research on cloning was certainly initially designed to study the mechanisms of cellular differentiation. But it was logical that the question of a possible dedifferentiation of cells should soon present itself. As Nicole Le Douarin writes:

The goal of pioneering experiments on cloning sought to explain one of the great questions of life: how are multicellular organisms in which the division of labor between cells is the rule built? The curiosity of biologists’ obviously led them to ask a general question about this phenomenon. Are the nuclei of differentiated cells of higher level organisms such as mammals capable, like those of amphibians, of being

\footnotetext{
${ }^{13}$. Quoted in Jean-Yves Nau, "Quand Les Cellules du cerveau se mettent à produire du sang,” Le Monde, 23 Jan. 1999, www.lemonde.fr/archives/article/1999/01/23/quand-lescellules-du-cerveau-se-mettent-a-produire-dusang_3533393_1819218.html?xtmc=quand_les_cellules_du_cerveau_se_mettent_a_produire _du_sang\&xtcr=3
} 
reprogrammed in order to reclaim the particular and unique state of the nucleus of the egg ${ }^{14}$

In other words, is it possible to reach the primary state of the cell at the embryonic stage where the cells are not yet specialized? Le Douarin’s response is as follows:

The experimental methods that would have made it possible to answer this question were not available in the 1960s. It was only later that the growing of the mammal egg and embryo became possible, thereby opening up very interesting research fields. It enabled the arrival of biotechnologies that led to human assisted reproductive technologies (ART), the production of embryonic stem cells from 1981, the cloning of Dolly the sheep in 1996, and that of many other species of mammals since then. [C, p. 160]

Let’s try to take stock of this list by emphasizing two biotechnological operations made on the cell: first, the production of embryonic stem cells as the basis for a first type of cloning known as therapeutic cloning, second, the cloning of mammals, known as reproductive cloning. These two operations prove the possibility of a reversibility of cellular differentiation and thereby upset a dogma that, until then, was viewed as definitive.

\footnotetext{
${ }^{14}$. Nicole Le Douarin, Les Cellules souches, porteuses d'immortalité (Paris, 2007), p. 160; hereafter abbreviated $C$.
} 
The challenge that cloning makes to the category of difference is not related primarily to the copy, to the threat of an eternal return of the same, for the clone will never be a faithful and perfect copy:

Epigenesis is a powerful determinant in development $[\ldots]$ in so far as it regulates gene functions and the establishment of neuronal networks. It is even more significant for the development of the singularity, aspirations and talents of each individual. The environment in which the becoming human lives plays a considerable role in this field. [C, p. 334]

If, therefore, the possibility of reproduction via cloning presents the problem of difference, this is not to be sought initially in the economy of the replica. The site of the problem, within the dialectical relation between epigenetics and cloning, is more that of the unidirectional and definitive nature of cellular differentiation, the program and the trace. In other words, the stakes are tied to the possibility of going back to a time before difference. Indeed, the radical novelty of the concept of the living being elaborated today by biology is paradoxically related to the return of cellular potentials, present among primitive animals and that were thought to have disappeared, or at least weakened, among so-called higher order animals. These potentials are precisely asexual reproduction and regeneration, both of which represent ancient forms of life realized by the state of the art technologies of therapeutic and reproductive cloning. Biotechnological innovation—far from being a mere 
instrumentalization, manipulation, or mutilation — thereby realizes a memory, that of the living beings erased within us. The posthuman is thus also the prehuman. On this dimension of return to nature of the technology, not a word has ever been said by any philosopher.

\section{Repairing, Regenerating: The Interplay of Possibilities}

In the course of evolution, regeneration — that possibility of naturally repairing all or part of the body — has largely been lost among mammals. This is why the discovery of stem cells_-able to repair, reform, and regenerate organs and damaged tissue—forces us to look two ways at once, both to the future and to the past: to the future, that is, towards the perfecting of technology destined for the medical use of these cells; and to the past, as regeneration is a very ancient property, connected to primitive animals, such as hydra, planarians and starfish.

In many ways, advances in biology are bringing back, or renewing, a period that was believed to be past. Jean-Claude Ameisen interprets this interplay of return as a play of possibilities. Possibilities that must be “drawn from their slumber”: We "could try to renew ourselves and to become perpetual starting from our own stem cells, starting from the spores that sleep in our body."15

\footnotetext{
${ }^{15}$. Jean-Claude Ameisen, La Sculpture du vivant: Le suicide cellulaire ou la mort créatrice (Paris, 1999), p. 322.
} 
And he adds:

The innumerable innovations of the living are built . . . on the basis of thetemporary—repression of most of their potentialities. And the wealth of these potentialities that sleep in the depths of our body no doubt surpass by far anything that we can yet imagine. ${ }^{16}$

At the heart of contemporary biological research lies the reactivation of phylogenetic remains that we believed to be forever lost.

And how might the return of these possibilities offer a power of resistance? The resistance of biology to biopolitics? It would take the development of a new materialism to answer these questions, a new materialism asserting the coincidence of the symbolic and the biological. There is but one life, one life only.

Biological potentials reveal unprecedented modes of transformation: reprograming genomes without modifying the genetic program; replacing all or part of the body without a transplant or prosthesis; a conception of the self as a source of reproduction. These operations achieve a veritable deconstruction of program, family, and identity that threatens to fracture the presumed unity of the political subject, to reveal the impregnable nature of its "biological life" due to its plurality. The articulation of political discourse on bodies is always partial, for it cannot absorb everything that the structure of the living being is able to burst open by

\footnotetext{
${ }^{16}$. Ibid., p. 323.
} 
showing the possibilities of a reversal in the order of generations, a complexification in the notion of heritage, a calling into question of filiation, a new relation to death and the irreversibility of time, through which emerges a new experience of finitude. 